\title{
A General Review of Recent Reports on Homosexuality and Lesbianism by John R. Hughes
}

\author{
Harm J. Hospers
}

Published online: 22 April 2008

(C) Springer Science+Business Media, LLC 2008

\section{Erratum to: Sex Disabil}

DOI 10.1007/s11195-008-9079-7

Dr. Hospers's correct email address is: H.Hospers@Psychology.Unimaas.NL

The online version of the original article can be found under doi:10.1007/s11195-008-9079-7.

H. J. Hospers $(\bowtie)$

Experimental Health Psychology and Homosexuality, Maastricht University,

Maastricht, The Netherlands

e-mail: H.Hospers@Psychology.Unimaas.NL 